Review

\title{
Some Implications of High Biodiversity for Management of Tropical Marine Ecosystems-An Australian Perspective
}

\author{
Richard Kenchington ${ }^{1}$ and Pat Hutchings ${ }^{2, *}$ \\ 1 Australian National Centre for Ocean Resources and Security, University of Wollongong, \\ Wollongong NSW 2522, Australia; rkenchin@uow.edu.au \\ 2 Australian Museum Research Institute, Australian Museum, 1 William Street, Sydney NSW 2010, Australia \\ * Correspondence: pat.hutchings@austmus.gov.au; Tel.: +61-293-206-243
}

Received: 22 August 2017; Accepted: 12 December 2017; Published: 21 December 2017

\begin{abstract}
While high biodiversity has been widely reported from the tropics, we suggest that in reality there is a considerable underestimate of the total biodiversity. We have concentrated on the tropical regions of Australia and the Coral Triangle. The best known groups are the corals, fish, and commercially important invertebrates. In considering whether this is true, we have concentrated on the diversity of benthic communities and water column communities which are poorly known. Yet at the bottom of the food chain these communities are highly dynamic and susceptible to the anthropogenic changes that are occurring with the rapid development in this highly populated region. Tropical biodiversity is under increasing stress from a synergistic combination of changes in climate, oceanographic regimes, increasing coastal development, overfishing, and poor water quality, resulting in bleaching of corals and loss of habitat and of associated fauna. These changes on reefs have received substantial research attention; in comparison, there is limited data on inter-reefal areas and water column communities and limited understanding of the ecological interconnectivity of all these habitats. While in this region there is growing marine protected area coverage, the major focus is on coral reefs with other habitats based on surrogacy with little if any ground-truthing. Within this region, there is limited capacity or inclination to rectify this lack of knowledge of the structure and ecology of the broader non-commercial benthic and pelagic communities. We suggest this lack of knowledge and limited expertise may be widespread throughout the tropics and compromises our ability to understand and predict the changes that are occurring with increasing anthropogenic impacts on these tropical ecosystems.
\end{abstract}

Keywords: biodiversity; benthic invertebrate infauna; epifauna; surrogacy

\section{Introduction}

Tropical marine biodiversity comprises species of warm waters, above an annual minimum of 18 degrees. Temperature profiles indicate that tropical waters typically occur between the surface and a depth of $250 \mathrm{~m}$ where, within the euphotic zone, there is consistent day length at the equator and a maximum summer/winter solstice difference of $2 \mathrm{~h}$ at the tropics. Subject to the distribution and availability of nutrients from oceanic upwelling or terrestrial runoff, this enables reasonably consistent primary productivity throughout the year. Monsoonal rains driving coastal and island runoff are typically an important driver of productivity of nearshore equatorial and tropical waters. Tropical biodiversity is under increasing stress from a synergistic combination of changes in climate, oceanographic regimes, increasing coastal development, overfishing, and poor water quality [1-3], resulting in bleaching of corals and loss of habitat and of associated fauna. 
The marine biodiversity of high latitude waters is shaped by a strong annual cycle of spring/summer productivity and abundance, with long day lengths and winter stress of low temperature and low light levels. Stresses that have shaped diversity in tropical waters are less consistent. They are influenced by variations in oceanic circulation such as the El Nino/La Nina Southern Oscillation, the extent and timing of monsoonal rains, and stochastic destructive impacts from severe storms or tsunamis.

In comparing speciation and endemism mechanisms of terrestrial and marine organisms, Dawson and Hamner [4] observed that the high dispersal ability, or water column linkage, of most marine organisms reduces physical limits to gene flow and thus increases the significance of suitable ecological conditions in separated but variably connected locations within a large area. In a substantial review of studies of the origins of abundant tropical marine biodiversity and diversity of patterns of speciation of tropical marine species, Bowen et al. [5] used the term biodiversity feedback to characterize the process whereby occasional variations and reversals of connectivity between hotspots and peripheral ecosystems enable local speciation along ecological boundaries, benefiting both.

Connell [6] and later Reaka-Kudla [7] recognised that coral reefs have levels of complexity similar to tropical rain forests but the extent of knowledge of the biodiversity and ecology of tropical water column and inter-reefal seabed habitats is relatively limited.

\subsection{Exceptional High Biodiversity of the Indo-Pacific Region}

Roberts et al. [8] analysed the global tropical/subtropical geographic range distributions of species of well documented families of corals, fish, molluscs, and large crustaceans, identifying 18 centres of coral reef associated endemism. The Indo-Pacific represents the single largest tropical biogeographical region both latitudinally and longitudinally [8]. The core global epicentre of marine biodiversity is the Coral Triangle in the Indo-Pacific Archipelago, an area with a human population of more than 120 million and consequent subsistence and commercial fishing activities [9], habitat loss [10], pollution [11], and other impacts from use and growing development of coastal areas [12]. Human communities of tropical islands and coastal areas have generally long depended on coastal biodiversity for local fishing and intertidal gleaning for food and materials and have used local knowledge and management practices to protect their resource areas [13].

Environmental science to inform conservation of the high biodiversity and ecosystem services of tropical marine ecosystems shares with fisheries the "shifting baseline" problem [14] of design and conduct of research and management in the context of historic and changing human activities. The degradation of the charismatic biodiversity of coral reefs summarised by Knowlton and Jackson [15] is widely recognised, but tropical marine biodiversity more generally is also facing unprecedented anthropogenic stress. Recent surveys in the Gulf of Carpentaria have shown large scale dieback of mangroves which coincided with a severe drought and a temporary drop in sea-level, as well as unprecedented high temperature [16]. This coincided with heat stressed coral bleaching on the Great Barrier Reef $[17,18]$, highlighting the complexity of interactions in tropical systems.

Most of the studies of tropical marine biodiversity in the Australasian region address shallow coastal and archipelagic areas [19]. These have provided reasonable coverage of the intertidal and shallow subtidal diversity of coral reef, seagrass, and mangrove habitats and of benthic species of fish, molluscs, crustaceans, and larger echinoderms of current or potential commercial interest. A similar pattern of knowledge is found for other groups with reasonable knowledge of intertidal and shallow biodiversity declining rapidly as one moves offshore [20,21]. We suggest that even in the relatively well-known groups of fish, molluscs, crustaceans, and larger echinoderms, biodiversity has been seriously underestimated and certainly the numbers of undescribed species increases with depth and distance from the coast. Increasingly, studies are being undertaken to document the genetic diversity in these habitats [22-24], but we are still a long way from linking this diversity with morphological diversity. Currently, management of tropical habitats is based entirely on morphological entities, although, as molecular studies are undertaken, many species are being shown to represent suites of species (e.g., fish [25] corals [26]). 
Mangroves provide extensive nutrient rich structural coastal habitats with sediments and sheltered waters providing ecological niches for complex communities of fish, as the epifaunal and infaunal species with significant degrees of endemism [27]. The structure and exposure of coral reefs provide multiple habitats [28] supporting biodiverse communities with high levels of diversity and life cycle strategies ranging from attached or limited territory species to those with significant duration of larval development and dispersal in the primary productive habitat of the water column.

In contrast, our knowledge of the invertebrate fauna of soft sediment inter-reefal habitats and the water column is poor. The water column communities include both permanent members and temporary ones that are the pelagic larvae of species that, as adults, are infaunal, largely sedentary, or territorial components of the fauna of sedimentary or rocky seabeds, coral reefs, or algal or seagrass beds. We have limited knowledge and lack taxonomic inventories or distribution patterns. Increasingly, we are finding that species have discrete distributions rather than widespread distributions which have often previously been reported [29]. Our taxonomic capacity in much of this region is limited with most residing in the capital cities of southern Australia, with developing countries in the region having other priorities.

This lack of knowledge seriously restricts our ability to predict both the changes which may occur in these communities with increasing anthropogenic impacts and how these may impact on other habitats within the region. Although seagrass beds act as nursery grounds for many species [30]. We have a poor understanding of the linkages between soft bottom and pelagic communities and coral reefs or seagrass beds [31-33].

A global review of over 100 marine biodiversity studies found 33,000 species that included an average of $37 \%$ (median 31\%) undescribed species which were primarily invertebrates from tropical and offshore environments [34] where there is no long tradition of benthic studies. Reefal studies dominated these studies with few inter-reefal habitats sampled.

A survey off the tropical north-west Australian coast which sampled benthic infauna may illustrate the extent of the greater level of undescribed species in tropical environments [13]. At least 805 species of crustaceans (only partially identified) and polychaetes were recorded from the bathyal continental margin. Of the identified crustaceans, $94 \%$ were undescribed and $72 \%$ of polychaetes were new to the Australian fauna [35]. It will be some time before all these species are formally described.

Even in well studied areas, like the Great Barrier Reef, we lack comprehensive data on those sedimentary seabed epifauna and infauna species which occupy the bottom of the food chain. Studies of inshore waters to the south of the Great Barrier Reef $[36,37]$ observed that infaunal communities are highly dynamic and sampling before and after a major flood demonstrated a complete change of the benthic fauna. Such benthic communities contain highly productive species which typically have short life spans and are most sensitive to changes in the environment. There is some data to indicate that some species are moving south with increasing water temperature (cited below) but, obviously, this depends on suitable substrate being available. The range shifting of tropical herbivores has led to increased grazing pressure, a resultant decline in macroalgal biomass, the prevention of recovery by continuous grazing, and ultimately, phase shifts to alternative ecosystem states [38]. As well as native species moving in response to climate change, there is good data to show that increasing water temperatures facilitate the introduction of non-native warm water species [39]. This is of concern in north-western Australia and along the Great Barrier Reef where increased port development is occurring and with it the increased probability of introductions via ballast water or hull fouling.

\subsection{Ecological Studies}

Most ecological studies are conducted at accessible sites that were subject to human use and impact before substantial programs of systematic survey and experimental research began around the mid-1960s. The lack of baseline data and the "shifting baseline" problem [15] present challenges for the provision of science to inform conservation of the high biodiversity and ecosystem services of tropical marine ecosystems in the context of changing human activities. Knowlton et al. [16] discuss the effects 
of local impacts and global change on the charismatic biodiversity of coral communities and the lack of undisturbed baseline reference sites for coral reefs. Coral reefs account for approximately $35,000 \mathrm{~km}^{2}$ or $10 \%$ of the area of the Great Barrier Reef Marine Park [40]. Similar comments can be made about the less studied inter-reefal soft sediment habitats, and the $6000 \mathrm{~km}^{2}$ of Halimeda meadows and bioherms that have received very little scientific attention in tropical coastal and shallow shelf waters [41]. While cross shelf transects have been carried out along the Great Barrier Reef, to study the impact of trawling on these inter-reefal habitats infauna was not identified and only gross classifications of epifaunal communities were made [42].

\section{The State of Knowledge of Tropical Marine Biodiversity}

The biodiversity and ecosystem linkages of water column ecosystems and the infauna and epifauna of tropical sedimentary seabeds are poorly understood. Compared to knowledge of coral reefs we lack a comprehensive database of the dominant benthic communities.

Some species recently described in northern Australia probably occur also beyond these waters in the Coral Triangle, but this still needs to be confirmed. Increasingly, as species are investigated in detail using both morphological and molecular data they are found to represent suites of cryptic species; therefore, some of the Indo-Pacific species need to be revisited and species lists reconciled between regions. Recently, Hutchings et al. [43] reviewed the historical data of the benthic polychaetes from the Kimberleys, NW Australia and suggested that many of the recorded species need to be re-examined and compared to the material recently collected during annual surveys for the past five years co-ordinated by the West Australian Museum. This work is revealing a large number of undescribed species.

Despite the logistical problems of systematic collection, lack of taxonomic capacity has led to large and growing amounts of unsorted material from oceanographic cruises and inshore surveys housed in all Australian natural history museums and laboratories [44,45]. While the capacity for taxonomic identification is limited, the available data on identified material from the Australasian region is far more accessible with museum collection data continually being uploaded to Australian Faunal Directory (AFD) and to the Atlas of Living Australia (ALA). This data is freely available and feeds into WoRMS (World Register of Marine Species). We suggest that basically we do not know if, how, or why these benthic infaunal communities are changing, but we do know that they are highly dynamic and highly sensitive to habitat destruction $[36,37,46]$.

While we have good data on increasing frequency of coral bleaching stress associated with increased water temperatures $[47,48]$, there is little appreciation of the associated fauna of live coral that will become locally extinct when a coral colony dies [49-51]. Earlier, Holbrook [52] showed that coral dwelling fishes are very sensitive to loss of live coral and sedimentation and eutrophication arising from coastal development as they typically have small population sizes which makes them extremely vulnerable to extinction from human induced disturbances on reefs. Similar findings were reported by Jones et al. [53].

Also, once coral colonies die they are increasingly susceptible to bioerosion [54] and if coral mortality is high after a bleaching event, increased rates of bioerosion [48] will lead to loss of reefal substrates and impact on any subsequent recruitment by corals.

We also have good regional data on water quality in some parts of the Coral Triangle and how this changes after major monsoonal or cyclonic catchment runoff [55]. The frequency and severity of such events is increasing with climate change.

The majority of the benthic fauna has two distinct life stages, a pelagic larval stage of varying duration and a sedentary benthic adult stage highly dependent on substrate type. The pelagic larval stage is largely passive and dispersed by water currents hopefully to suitable habitats for successful settlement, but high mortality of larvae occurs. These pelagic larvae provide food for a wide range of organisms higher up in the food chain. 


\section{The Data Challenge for Managing Marine Biodiversity}

Management of biodiversity should be an iterative and adaptive process. It typically starts with limited contemporary understanding of biological and socio-political opportunities and constraints and against a background of past impacts. The development of an initial plan typically requires new knowledge in a short time for framing the vision and decision criteria for management, it also requires measurable objectives against which management may be assessed. Implementation requires systematic collection of biological and socio-political data and research to inform reviews of experience and the longer-term outlook for achieving or maintaining the vision and objectives [56].

We know anecdotally that the area to the west of the Swains complex at the southern end of the Great Barrier Reef was 'cleared' by Taiwanese pair trawlers with chains in the late 1960s early $70 \mathrm{~s}$ that brought up the remains of $2 \mathrm{~m}$ high Turbinaria vase forming corals which would have been decades if not centuries old. At the time of the initial planning of the Great Barrier Reef Marine Park, there was an established nearshore small vessel trawl fishery for prawns with growing exploratory and production trawling further offshore. Significant trawl fisheries for prawns, Moreton Bay bugs, scallops, and squid are sustained in 5\% of the area of the Great Barrier Reef Marine Park.

The lack of data on benthic communities and remote areas was an issue in establishing the Great Barrier Reef Marine Park in the 1970s. Historical biodiversity information, especially in non-reefal areas, reflected a focus on fishery resources [57] and coral reefs [58]. The inter-reefal habitats were largely unsurveyed and undescribed and thus received relatively little attention during the original zoning of the Great Barrier Reef Marine Park between 1979 and 1988.

The Great Barrier Reef (GBR) was accepted for inscription on the World Heritage List in 1982 on the basis of a brief nomination describing the holistic nature of outstanding universal value in a very large interconnected marine ecosystem. At that time the nomination process did not require greater specificity in identification of values but the information requirements for later nominations became more detailed. Consequently, in 1995 the Great Barrier Reef Marine Park Authority commissioned a consultant review of the outstanding universal value of the GBR World Heritage Area, with particular attention to the knowledge and protection of its biodiversity. This review [59] noted the limitations in knowledge of non-reefal biota and recommended revision of management to ensure that representative areas of all habitats were included in no-take protected areas.

These experiences informed an initiative to develop a national regionalisation of marine habitats of Australian coastal and offshore waters. An Interim Marine and Coastal Regionalisation of Australia (IMCRA 3.3), Environment Australia 1998 [60] provided a synthesis of diverse existing data sets that identified 60 meso-scale eco-regions, 8 of which were represented in the Great Barrier Reef region.

The lack of biodiversity data encouraged the use of physical surrogacy with limited ground-truthing of benthic/planktonic data. A decade of geomorphic survey with limited benthic sampling in Australia's Exclusive Economic Zone provided a framework for surrogacy and extrapolation from available data. This informed the development of an Integrated Marine and Coastal Regionalisation of Australia (IMCRA 4.0), Environment Australia [61] identifying 41 Provincial bioregions, of which 19 were tropical and 3 encompassed the Great Barrier Reef World Heritage Area. For the 2003 rezoning of the Great Barrier Reef Marine Park, more detailed local knowledge of habitats and biodiversity in the Great Barrier Reef bioregions was used to further resolve the 3 provincial bioregions into 30 reef and 40 non-reef planning units, enabling the establishment of a system of no-take areas representative of the biodiversity of the Great Barrier Reef World Heritage Area [62].

The situation is similar for much of the Coral Triangle where very little is known about the benthic invertebrate biodiversity apart from corals. In many sites, such information is not of high national priority for developing countries. While there is a lack of taxonomic expertise in some areas of the Coral Triangle there is substantial material and data collected during numerous benthic surveys in the region. It is critically important that material collected during these surveys is properly documented and lodged in permanent storage facilities for future research. The costs are small in comparison to the cost of the original surveys. 
There is currently growing research interest in the impacts on coral reefs and algal assemblages of fishing for top predators and herbivores. Experimental studies have demonstrated that realistic models of sharks and large serranids led to reduced grazing and species richness of herbivorous fishes while smaller serranids reduced herbivore diversity and activity to a lesser extent [63]. The implications for biodiversity of the interactions of predators, herbivores, and human impacts on the distribution of algae and associated biota are not yet well understood and are an important consideration for informing management of marine biodiversity.

The logistic challenges of vessel availability, tidal range, weather, operational safety for small boats, and safe anchorage for mother ships, can present practical constraints and introduce sampling bias by influencing where field research is undertaken. In some tropical areas, such as north-western Australia, sampling design for intertidal and shallow subtidal studies can require consideration of additional local logistical challenges such as $4 \mathrm{~m}$ tides and healthy populations of crocodiles.

The data and logistical challenges of scale for understanding the effects of marine biodiversity management measures are illustrated by the study of Carter et al. [64] comparing population structure and egg production per unit area (EPUA) of the fished species Plectropomus leopardus in fished and no take marine reserves (NTMR) in the geographic regions of the GBR from 2004 to 2013. This study found that within a geographic region, NTMR status, fish size and population density all affected EPUA but regional differences were substantial. Comparing NTMR reefs with fished reefs, the EPUA was $21 \%$ greater in the southern region; $152 \%$ greater in the central region but $56 \%$ less in the northern region. EPUA was found to vary at both small and large spatial scales. Despite the southern GBR having two to four times greater densities of than the other regions, the EPUA was at least one order of magnitude lower.

\section{Discussion}

Our knowledge of benthic epi- and infauna communities is limited, but we know that they are highly dynamic and sensitive to habitat destruction. The shifting baseline for coral reefs [14] must also apply to benthic communities but the implications for biodiversity of the interactions of predators, herbivores, and human impacts on the distribution of algae and associated biota are not yet well understood and should be an important consideration for informing management of marine biodiversity.

Fish populations in areas in north-western Australia, which were extensively trawled, have dramatically changed as the original three-dimensional nature of the substrate-formed by sponges, soft corals, etc.-has been completely removed and replaced with uniform mud [46]. Here and elsewhere where extensive trawling has occurred benthic communities will also have been substantially modified.

Areas that have been subject to production or exploratory trawling may take decades to recover to the extent that slow growing sponges and deep water corals can again modify benthic currents. Such currents are critical for providing the three-dimensional habitat for larval recruitment $[32,65]$ and adult habitat of other organisms to colonise [66].

Widespread coral bleaching events have become predominant impacts on coral reef communities. Recent consecutive events in 2016 and 2017 respectively on the northern and central sections of the Great Barrier Reef $[17,18]$ have caused widespread coral death. Once coral colonies die, they are increasingly susceptible to bioerosion [53]. Increased rates of bioerosion will lead to loss of reefal substrates and impact on any subsequent recruitment of corals. Where there has been some recovery of coral cover after earlier bleaching, the increased frequency of recent events raises concern at the likelihood of substantial changes in coral reef biodiversity and loss of coral reef substrate by increased rates of bioerosion [53]. The same is likely to be the case for benthic-pelagic components of the fauna at the bottom of the food chain which typically have short life spans and are sensitive to changes in the environment [36,37]. 
Surrogacy, based primarily on seabed geology and fishery related data, has enabled progress in identifying provincial bioregions, but the scale may be too coarse to resolve local biodiversity particularly in nearshore areas. In the case of the rezoning of the Great Barrier Reef, 3 provincial scale bioregions were addressed, with 70 fine bioregional planning units identified with some further research data and a further level of surrogacy based on structurally dominant groups such as sponges, soft corals, seagrass, Halimeda, and algal beds.

Gladstone and Hutchings [66] have tested the validity of using surrogacy on benthic infaunal communities over a three year sampling period, and found inconsistent patterns for a subtropical protected bay, however there is no comparative data for Australian tropical areas.

\section{Conclusions}

Observations of poleward migration of some species in the context of ocean warming suggest that there are likely to be, in tropical areas, changes in the composition of communities to species that can tolerate or adapt to warmer conditions. The extent to which such changes may affect the ecosystem provisioning services for fisheries, the regulating services of coastal protection or the cultural services and values of tropical marine systems is unclear.

There are major gaps in the broad area knowledge of the tropical marine fauna of Australia as outlined above. This is particularly the case for benthic and pelagic components of the fauna, which are at the bottom of the food chain and typically have short life spans and are likely to be most sensitive to changes in the environment.

We stress that tropical biodiversity is being subjected to major changes through anthropogenic impacts, yet we have little understanding of these changes with regard to the major components of the complex marine food webs and distribution linkages or the implications for human populations which depend on these ecosystems. While an increasing area of global coral reef and associated tropical marine ecosystems is being included in marine protected areas, management agencies generally have inadequate access to resources or expertise, either for managing such areas, or for enabling robust monitoring of the effectiveness of broader management strategies.

Author Contributions: Richard Kenchington and Pat Hutchings contributed equally to the paper.

Conflicts of Interest: The authors declare no conflict of interest.

\section{References}

1. Great Barrier Reef Marine Park Authority. Great Barrier Reef Outlook Report 2009. Available online: http:// www.gbrmpa.gov.au/managing-the-reef/great-barrier-reef-outlook-report/outlook-report-2009 (accessed on 19 October 2017).

2. Great Barrier Reef Marine Park Authority. Great Barrier Reef Outlook Report 2014. Available online: http:// www.gbrmpa.gov.au/managing-the-reef/great-barrier-reef-outlook-report/outlook-report-2014 (accessed on 18 October 2017).

3. WWF Coral Triangle Problems. Available online: http://wwf.panda.org/what_we_do/where_we_work/ coraltriangle/problems (accessed on 18 October 2017).

4. Dawson, M.N.; Hamner, W.M. A biophysical perspective on dispersal and the geography of evolution in marine and terrestrial systems. J. R. Soc. Interface 2008, 5, 135-150. [CrossRef] [PubMed]

5. Bowen, B.W.; Rocha, L.A.; Toonen, R.J.; Karl, S.A. The origins of tropical marine biodiversity. Trends Ecol. Evol. 2013, 28, 359-366. [CrossRef] [PubMed]

6. Connell, J.H. Diversity in Tropical Rain Forests and Coral Reefs. Science 1978, 199, 1302-1310. [CrossRef] [PubMed]

7. Reaka-Kudla, M. The global biodiversity of coral reefs: A comparison with rain forests. In Biodiversity II: Understanding and Protecting Our Biological Resources; Reaka-Kudla, M., Wilson, D.E., Wilson, E.O., Eds.; Joseph Henry Press: Washington, DC, USA, 1997; pp. 83-108. 
8. Roberts, C.M.; McClean, C.J.; Veron, J.E.N.; Hawkins, J.P.; Allen, G.R.; McAllister, D.E.; Mittermeier, C.G.; Schuele, F.W.; Spalding, M.; Wells, F. Marine Biodiversity Hotspots and Conservation Priorities for Tropical Reefs. Science 2002, 295, 1280-1284. [CrossRef] [PubMed]

9. Bellwood, D.R.; Hughes, T.P. Regional-scale assembly rules and biodiversity of coral reefs. Science 2001, 292, 1532-1535. [CrossRef] [PubMed]

10. Munday, P.L. Habitat loss, resource specialization, and extinction on coral reefs. Glob. Chang. Biol. 2004, 10, 1642-1647. [CrossRef]

11. Fisher, C.R.; Demopolous, A.J.; Cordes, E.E.; Baum, I.B.; White, H.K.; Bourque, J.R. Coral communities as indicators of Ecosystem Level impacts of Deepwater Horizon spill. BioScience 2014, 64, 796-807. [CrossRef]

12. Brodie, J.; Pearson, R. Ecosystem health of the Great Barrier Reef: Time for effective management action based on evidence. Estuar. Coast. Shelf Sci. 2016, 183, 438-451. [CrossRef]

13. Johannes, R.E. Words of the Lagoon; University of California Press: Berkeley, CA, USA, 1981; p. 245.

14. Pauly, D. Anecdotes and the shifting baseline syndrome of fisheries. Trends Ecol. Evol. 1995, 10, 430. [CrossRef]

15. Knowlton, N.; Jackson, J. Shifting baselines, local impacts and global change on coral reef. PLoS Biol. 2008, 6, 215-220. [CrossRef] [PubMed]

16. Duke, N.C.; Kovacs, J.M.; Griffiths, A.D.; Preece, L.; Hill, D.J.E.; van Oosterzee, P.; Mackenzie, J.; Morning, H.S.; Burrows, D. Large-scale dieback of mangroves in Australia's Gulf of Carpentaria: A severe ecosystem response, coincidental with an unusually extreme weather event. Mar. Freshw. Res. 2017, 68, 1816-1829. [CrossRef]

17. Hughes, T.P.; Kerry, J.T.; Álvarez-Noriega, M.; Álvarez-Romero, J.G.; Anderson, K.D.; Baird, A.H.; Babcock, R.C.; Beger, M.; Bellwood, D.R.; Berkelmans, R. Global warming and recurrent mass bleaching of corals. Nature 2017, 543, 373-377. [CrossRef] [PubMed]

18. Hughes, T.P.; Kerry, J.; Connolly, S. Two-Thirds of Great Barrier Reef Hit by Back to back Mass Coral Bleaching. Available online: https://www.jcu.edu.au/news/releases/2017/april/two-thirds-of-greatbarrier-reef-hit-by-back-to-back-mass-coral-bleaching (accessed on 18 October 2017).

19. Bouchet, P.; Lozouet, P.; Maestrati, P.; Heros, V. Assessing the magnitude of species richness in tropical marine environments: Exceptionally high numbers of molluscs at a New Caledonia site. Biol. J. Linn. Soc. Lond. 2002, 75, 421-436. [CrossRef]

20. Hoeksma, B.W. Delineation of the Indo-Malayan Centre of Maximum Marine Biodiversity: The Coral Triangle. In Biogeography, Time, and Place: Distributions, Barriers, and Islands; Renema, W., Ed.; Springer: Dordrecht, The Netherlands, 2007; pp. 117-178.

21. Poore, A.G.; Gutow, B.L.; Pantoja, J.; Tala, F.; Jofré Madariaga, D.; Thiel, M. Major consequences of minor damage: Impacts of small grazers on fast growing kelps. Oecologia 2014, 174, 789-801. [CrossRef] [PubMed]

22. Plaisance, L.; Knowlton, N.; Paulay, G.; Meyer, C.P. Reef-associated crustacean fauna: Biodiversity estimates using semi-quantitative sampling and DNA barcoding. Coral Reefs 2009, 28, 977-986. [CrossRef]

23. Plaisance, L.; Caley, M.J.; Brainard, R.E.; Knowlton, N. The Diversity of Coral Reefs: What Are We Missing? PLoS ONE 2011, 6, e25026. [CrossRef] [PubMed]

24. Leray, M.; Knowlton, N. DNA barcoding and metabarcoding of standardized samples reveal patterns of marine benthic diversity. PNAS 2015, 112, 2076-2081. [CrossRef] [PubMed]

25. Montanari, S.R.; Hobbs, J.-P.A.; Pratchett, M.S.; van Herwerden, L. The importance of ecological and behavioural data in studies of hybridisation among marine fishes. Rev. Fish Biol. Fisher. 2016, 26, 181-198. [CrossRef]

26. Richards, Z.T.; Hobbs, J.-P.A. Hybridisation on coral reefs and the conservation of evolutionary novelty. Curr. Zool. 2015, 61, 132-145. [CrossRef]

27. Field, C.B.; Osborn, J.G.; Hoffman, L.L.; Polsenberg, J.F.; Ackerly, D.D.; Berry, J.A.; Bjorkman, O.; Held, A.; Matson, P.A.; Mooney, H.A. Mangrove biodiversity and ecosystem function. Glob. Ecol. Biogeogr. Lett. 1998, 7, 3-14. [CrossRef]

28. Kramer, M.J.; Bellwood, O.; Bellwood, D.R. The trophic importance of algal turfs for coral reef fishes: The crustacean link. Coral Reefs 2013, 32, 575-583. [CrossRef]

29. Hutchings, P.A.; Kupriyanova, E. Cosmopolitan species, fact or fashion? A personal perspective. Invertebrate Systematics. Invertebr. Syst. 2017, in press. 
30. Honda, K.; Nakamura, Y.; Nakaoka, M.; Uy, W.H.; Fortes, M. Habitat Use by Fishes in Coral Reefs, Seagrass Beds and Mangrove Habitats in the Philippines. PLoS ONE 2013, 8, e65735. [CrossRef] [PubMed]

31. Nagelkerken, I.; Dorenbosch, M.; Verberk, W.C.E.P.; Cocheret de la Morinière, E.; van der Velde, G. Importance of shallow water biotopes of a Caribbean bay for juvenile coral reef fishes: Patterns in biotope association, community structure and spatial distribution. Mar. Ecol. Prog. Ser. 2000, 202, 175-192. [CrossRef]

32. Nagelkerken, I.; van der Velde, G.; Gorissen, M.W.; Meijer, G.J.; van't Hof, T.; den Hartog, C. Importance of mangroves, seagrass beds and the shallow coral reef as a nursery for important coral reef fishes, using a visual census technique. Estuar. Coast. Shelf Sci. 2000, 5, 31-44. [CrossRef]

33. Unsworth, R.K.F.; De Leon, P.S.; Garrard, S.L.; Jompa, J.; Smith, D.J.; Bell, J.J. High connectivity of Indo-Pacific seagrass fish assemblages with mangrove and coral reef habitats. Mar. Ecol. Prog. Ser. 2008, 353, $213-224$. [CrossRef]

34. Appeltans, W.; Ahyong, S.T.; Anderson, G.; Angel, M.V.; Artois, T.; Bailly, N.; Bamber, R.; Barber, A.; Bartsch, I.; Berta, A.; et al. The Magnitude of global marine species diversity. Curr. Biol. 2012, 22, 2189-2202. [CrossRef] [PubMed]

35. Poore, G.C.B.; Avery, L.; Błazewicz-Paszkowcz, M.; Browne, J.; Bruce, N.L.; Gerken, S.; Glasby, C.; Greaves, E.; McCallum, A.W.; Staples, D.; et al. Invertebrate diversity of the unexplored marine western margin of Australia: Taxonomy and implications for global biodiversity. Mar. Biodivers. 2015, 45, 271-286. [CrossRef]

36. Stephenson, W.; Williams, W.T.; Lance, G.N. The macrobenthos of Moreton Bay. Ecol. Mon. 1970, 40, $459-494$. [CrossRef]

37. Stephenson, W.; Williams, W.T.; Cook, S.D. The benthic fauna of soft bottoms, southern Moreton Bay. Mem. Qld. Mus. 1974, 17, 73-123.

38. Wernberg, T.; Bennett, S.; Babcock, R.C.; de Bettignies, T.; Cure, K.; Depczynski, M.; Dufois, F.; Fromont, J.; Fulton, C.J.; Hovey, R.K.; et al. Climate-driven regime shift of a temperate marine ecosystem. Science 2016, 353, 169-172. [CrossRef] [PubMed]

39. Przeslawski, R.; Ahyong, S.; Byrne, M.; Wörheide, G.; Hutchings, P. Beyond corals and fish: The effects of climate change on non-coral benthic invertebrates of tropical reefs. Glob. Chang. Biol. 2008, 14, 2773-2795. [CrossRef]

40. Harris, P.T.; Bridge, T.C.L.; Beaman, R.J.; Webster, J.M.; Nichol, S.L.; Brooke, B.P. Submerged banks in the Great Barrier Reef, Australia, greatly increase available coral reef habitat. ICES J. Mar. Sci. 2013, 70, $284-293$. [CrossRef]

41. McNeil, M.A.; Webster, J.M.; Beaman, R.J.; Graham, T.L. New constraints on the spatial distribution and morphology of the Halimeda bioherms of the Great Barrier Reef, Australia. Coral Reefs 2016, 35, 1343-1355. [CrossRef]

42. Pitcher, R.C.; Doherty, P.P.; Arnold, P.P.; Hooper, J.J.; Gribble, N.N. Seabed Biodiversity on the Continental Shelf of the Great Barrier Reef World Heritage Area; CSIRO Marine and Atmospheric Research: Canberra, Australia, 2007; p. 319.

43. Hutchings, P.A.; Glasby, C.J.; Capa, M.; Sampey, A. Synthesis of Historic Marine Data for the Kimberley, Western Australia (1880s-2009): Polychaetes (Annelida); Western Australian Museum: Northbridge, Australia, 2014; pp. 133-159.

44. Ponder, W.F.; Hutchings, P.A.; Chapman, R. Overview of the Conservation of Australia's Marine Invertebrates: A Report for Environment Australia. Available online: https://australianmuseum.net. au/.../documents/.../marine\%20invert\%20conservation\%20 (accessed on 19 October 2017).

45. Kenchington, R.A.; Hutchings, P. Science, biodiversity and Australian management of marine ecosystems. Ocean Coast. Manag. 2012, 69, 194-199. [CrossRef]

46. Hutchings, P.A. A review of the effects of trawling on macro benthic epifaunal communities. Mar. Freshw. Res. 1990, 41, 111-120. [CrossRef]

47. Donner, S.D.; Skirving, W.J.; Little, C.M.; Oppenheimer, M.; Hoegh-Guldberg, O. Global assessment of coral bleaching and required rates of adaptation under climate change. Glob. Chang. Biol. 2005, 11, 2251-2265. [CrossRef]

48. Hughes, T.P.; Kerry, J.T.; Simpson, T. Large-scale bleaching of corals on the Great Barrier Reef. Ecology 2017, 98, 2081-2092. [CrossRef] [PubMed]

49. Pari, N.; Peyrot-Clausade, M.; Hutchings, P.A. Bioerosion of experimental substrates on high islands and atoll lagoons (French Polynesia) during 5 years of exposure. Exp. Mar. Biol. Ecol. 2002, 276, 109-127. [CrossRef] 
50. Stella, J.S.; Munday, P.L.; Walker, S.P.W.; Pratchett, M.S.; Jones, G.P. From cooperation to combat: Adverse effect of thermal stress in a symbiotic coral-crustacean community. Oecologia 2014, 174, 1187-1195. [CrossRef] [PubMed]

51. Stella, J.; Pratchett, M.S.; Hutchings, P.; Jones, G.P. Coral Associated invertebrates, diversity, ecological importance and vulnerability to disturbance. In Oceanography and Marine Biology: An Annual Review; CRC Press: Boca Raton, FL, USA, 2011; pp. 43-104.

52. Holbrook, S.J.; Schmitt, R.J.; Messmer, V.B.; Andrew, J.; Srinivasan, M.M.; Philip, L.; Jones, G.P. Reef fishes in biodiversity hotspots are at greatest risk from loss of coral species. PLoS ONE 2015, 10, e0124054. [CrossRef] [PubMed]

53. Jones, G.P.; McCormick, M.I.; Srinivasan, M.; Eagle, J.V. Coral decline threatens fish biodiversity in marine reserves. Proc. Natl. Acad. Sci. USA 2004, 101, 8251-8253. [CrossRef] [PubMed]

54. Hutchings, P.; Peyrot-Clausade, M.; Stuken, A. Internal macrobioerosion on five species of Acropora following the 1998 bleaching event: Implications for the long-term impact of bleaching on the Great Barrier Reef. Pac. Conserv. Biol. 2014, 19, 409-417. [CrossRef]

55. Brodie, J.; Fabricius, K.; De'Ath, G. Are increased nutrient inputs responsible for more outbreaks of crown-of-thorns starfish? An appraisal of the evidence. Mar. Pollut. Bull. 2005, 51, 266-278. [CrossRef] [PubMed]

56. Dobbs, K.; Day, J.; Skeat, H.; Baldwin, J.; Molloy, F.; McCook, L.; Johnson, M.; Elliot, B.; Skeat, A.; Vohland, K.; et al. Developing a long-term outlook for the Great Barrier Reef, Australia: A framework for adaptive management reporting underpinning an ecosystem based management approach. Mar. Policy 2011, 35, 233-240. [CrossRef]

57. Saville-Kent, W. The Great Barrier Reef of Australia: Its Products and Potentialities; John Currey: Melbourne, Australia, 1972; p. 387.

58. Yonge, C.M. Great Barrier Reef Expedition, 1928-1929: Scientific Reports; Trustees of the British Museum: London, UK, 2013; pp. 1930-1958.

59. Lucas, P.H.C.; Webb, T.; Valentine, P.S.; Marsh, H. The Outstanding Universal Value of the Great Barrier Reef World Heritage Area. Great Barrier Reef Marine Park Authority. Available online: http:/ / elibrary.gbrmpa. gov.au/jspui/handle/11017/301 (accessed on 19 October 2017).

60. Environment Australia, Commonwealth Department of the Environment. Interim Marine and Coastal Regionalisation of Australia (IMCRA 3.3). Available online: http:/ / www.environment.gov.au/resource/ interim-marine-and-coastal-regionalisation-australia-version-33 (accessed on 19 October 2017).

61. Environment Australia, Commonwealth Department of the Environment. A Guide to the Integrated Marine and Coastal Regionalisation of Australia: Version 4.0 June 2006 (IMCRA v4.0). Commonwealth Department of the Environment: Canberra, Australia. Available online: http:/ /www.environment.gov.au/resource/ guide-integrated-marine-and-coastal-regionalisation-australia-version-40-june-2006-imcra (accessed on 19 October 2017).

62. Fernandes, L.; Day, J.O.N.; Lewis, A.; Slegers, S.; Kerrigan, B.; Breen, D.A.N.; Cameron, D.; Jago, B.; Hall, J.; Lowe, D.; et al. Establishing representative no-take areas in the Great Barrier Reef: Large-scale implementation of theory on Marine Protected Areas. Conserv. Biol. 2005, 19, 1733-1744. [CrossRef]

63. Rizzari, J.R.; Frisch, A.J.; Hoey, A.S.; McCormick, M.I. Not worth the risk: Apex predators suppress herbivory on coral reefs. Oikos 2014, 123, 829-836. [CrossRef]

64. Carter, A.B.; Davies, C.R.; Emslie, M.J.; Mapstone, B.D.; Russ, G.R.; Tobin, A.J.; Williams, A.J. Reproductive benefits of no-take marine reserves vary with region for exploited coral reef fish. Sci. Rep. 2017, 7, 9693. [CrossRef] [PubMed]

65. Sebens, K.P.; Johnson, A.S. Effects of water movement on prey capture and distribution of ref corals. Hydrobiogia 1991, 216, 247-248.

66. Gladstone, W.; Hutchings, P. Cross-taxon biodiversity surrogacy varies in its persistence through time and between habitats. Biol. Conserv. 2017, submitted.

(C) 2017 by the authors. Licensee MDPI, Basel, Switzerland. This article is an open access article distributed under the terms and conditions of the Creative Commons Attribution (CC BY) license (http:/ / creativecommons.org/licenses/by/4.0/). 